\title{
ON THE ZOOCHORY OF SCHISTOSTEGA PENNATA (SCHISTOSTEGACEAE, MUSCI)
}

\section{ЗООХОРИЯ У SCHISTOSTEGA PENNATA (SCHISTOSTEGACEAE, MUSCI)}

\author{
Michael S. IGNATOV ${ }^{1} \&$ Elena A. IGNATOVA ${ }^{2}$ \\ М. С. ИГнатов ${ }^{1}$, Е. А. ИГНАТОвА ${ }^{2}$
}

Abstract

The spores of Schistostega pennata (Hedw.) Web. et Mohr have sticky surface and can not be freely dispersed by wind in fresh state. Also spore surface ornamentation is very similar to that of Splachnum, Tetraplodon and Aplodon, genera strictly adapted to entomochory; this allows to suggest the adaptation to zoochory in Schistostega. Other evidences of zoochory in Schistostega are based on its recent rapid expansion in some parts of Central Russia, on habitat peculiarities, and on some other parallels in morphology with Splachnaceae. The possible dispersal agents are discussed (birds, mammals, insects, spiders, etc.), but no one of them can be chosen as the main one, at least in the forests of Central Russia.

Резюме

Споры Schistostega pennata (Hedw.) Web. et Mohr имеют липкую поверхность и в свежем состоянии не могут распространяться ветром. Орнаментация поверхности спор весьма сходна с таковой Splachnum, Tetraplodon и Aplodon, родов, для которых показана исключительная адаптация к энтомохорному распространению спор. Это дает возможность предположить зоохорию как основной способ распространения диаспор у Schistostega. Дополнительными основаниями для такого заключения являются данные о недавнем быстром расселении Schistostega в Центральной России, особенностях ее экологии, а также прочих общих со Splachnaceae морфологических признаках. Возможными переносчиками диаспор могут быть разные животные (птицы, звери, насекомые, паукообразные и др.), но выявить главного распространителя спор в лесах Центральной России не удалось.

\section{INTRODUCTION}

Schistostega pennata (Hedw.) Web. et Mohr is the only member of the family Schistostegaceae. According to Stone (1986), the family belongs to the order Schistostegales, which includes only one more species, Mittenia plumula (Mitt.) Lindb. from its own family Mitteniaceae, distributed in the South America and Australasia. However, recent data based on DNA analysis (Beckert \& al., 1999, 2001; Samigullin $\&$ al.,1998) show close relationships of Schistostega with Dicranales (Fissidentaceae, Dicranaceae, Ditrichaceae) whereas Mittenia has double peristome and obviously is very distant evolutionary from mosses with single perisome; Buck \& Goffinet (2000) placed Mittenia close to Rhizogoniaceae.
Schistostega is not known outside Holarctic, where it is more common in the regions dominated by coniferous forests. This is a well-known species due to its peculiar feather-like sterile leaves and persistent luminous protonema. In many countries, Schistostega is considered as a rare moss. However, recent studies in the Central Russia revealed it to be a rather common species and probably also rapidly increasing its abundance.

During our observations on Schistostega in Central Russia, particularly in Moscow Province, some characters neglected in previous descriptions were revealed. They allow to suggest a zoochory in this species, which is parallel in certain respects to that in entomophilous genera of Splachnaceae. There are four groups of

1 - Main Botanical Garden of Russian Academy of Sciences, Botanicheskaya 4, Moscow 127276 Russia - Россия 127276 Москва, Ботаническая 4, Главный ботанический сад Российской Академии Наук

2 - Moscow State University, Biological Faculty, Moscow 119899 Russia - Россия 119899 Москва, Московский государственный университ, Биологический факультет 
evidences based on: (1) distribution in recent years in the Central Russia; (2) species morphology; (3) habitat peculiarities, and (4) some direct observations.

\section{DisTRIBUTION IN CENTRAL RUSSIA}

Moscow Province was relatively well collected in the early XIX centure by Goldbach, whose data were published mainly by FischerWaldheim (1864), and in 1890-1900s by Zickendrath, Heyden and some other collectors, and these results were published by Zickendrath (1900) and Warnstorf (1913-14). Schistostega was not reported in these papers. In that period this species was known in Karelia and St.Petersburg Province (the first record from Russia was done probably by H. Lindberg in St.Petersburg Province, 1897, LE). In 1920s more localities were found in St. Petersburg / Leningrad Province, and in 1927 Korchagin collected Schistostega also in Vologda Province, ca. $400 \mathrm{~km} \mathrm{~N}$ of Moscow (LE).

In Central Russia Schistostega was first found in Kaluga Province, SW of Moscow Province - in 1920s (Zhadovsky, 1928), but up to the recent time Schistostega was known here by the single locality in a rather peculiar area with sandstone outcrops and only since 1980s was found in several more places (Majorov, 2001). In 1938 this species was collected in Tver Province, $\mathrm{N}$ and NW of Moscow Province by Medvedskaya (LE, MHA; Ignatov \& al., 1998). In Moscow Province Schistostega was found for the first time in 1952 by Razumovsky and Kiseleva on steep slope to a small creek, under roots of Betula (LE; Ignatov \& al., 1988). The second collection has been done by Ignatov only in 1985, in the northern part of Moscow Province, under upturned roots of fallen pine. Since then Schistostega had been searched in similar habitats in different parts of Moscow Province in 1985-1987, and two more localities were found (Ignatov \& al., 1988); all these 3 localities were in sandy plains. In mid1990s, when we came back to the studies of bryophytes in Moscow Province, Schistostega was found already in quite a number of places, and not only on sandy soils, but also on loam, almost always on vertical soil walls at upturned roots of fallen trees. In many places it was seen on many upturnings. It seems, that the only need for its occurrence is the sufficient concentra- tion of fallen trees in spruce or pine (rarer Betula) forests. In the last decade such forests became more numerous, because more areas receive a status of partly protected forests with very restricted cuttings, so the fallen trees became more common. Also, the age of many forests came to mature, because a lot of area were cut or otherwise strongly damaged in 1940s, during the Second World War. Before this war in XIX and early XX centure, fallen trees probably were not very common in the Central Russia due to intensive usage of forests, so trees were cut, not fallen (Reczan \& al., 1993).

Two special areas in Moscow Province present a particular interest regarding to increase of Schistostega abundance. (1) Prioksko-Terrasnyj State Reserve has been carefully studied in 198688 (Ignatov \& Ignatova, 1991). In 1986 Schistostega was found on single and strongly declining upturning, so plants were transplanted to the neigboring one, and in 1988 Schistostega was found well adapted to this new place and found in 2 more places nearby; in 1997-2000 Schistostega was found nearly throughout the reserve, in each place we looked for it, and in many places it grew at many upturnings. (2) In 1997 Schistostega was found being not a rare moss in the Zvenigorod Biological Station of Moscow State University, and in 1998-2000 in that place it was found even more abundant, growing in some parts of spruce forest on ca. $80 \%$ of upturnings studied. The list of bryophytes of the territory of this station was published by Sluka (1986), and it does not include Schistostega. Though it is difficult to exclude absolutely that Schististega grew in early 1980s in some places in this area, it is obvious that its abundance increased greatly. Details of ecology of Schistostega in this area are given below.

In other parts of European Russia Schistostega was found in recent years as following places: Tver Province (Zentral Forest Reserve, 1994-97, common, in reserved forests), Archangelsk Prov. (Pinega Reserve, 1988, several places, in reserved forest); Kostroma and Vologda Prov. (5 localities, or nearly all places studied during several short stops, 1990), Nizhnij Novgorod Prov. (Kerzhensky Reserve, 1999, rare, forest was heavily cut until recently), Ryazan Prov. (Oksky Reserve, 1999, rare, forest was much cut in mid-XX centure). 

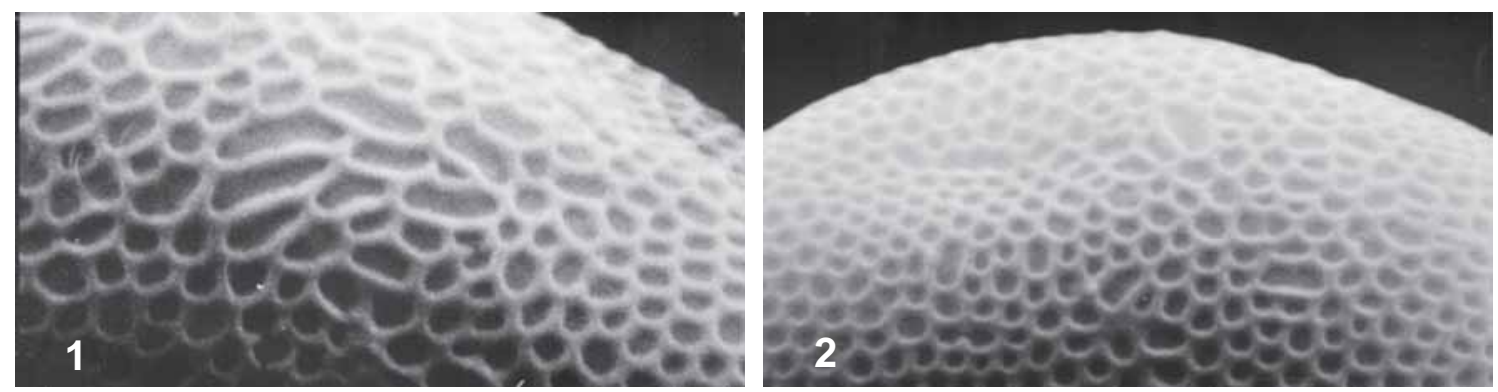

Fig. 1-2. Surface of spores of Schistostega pennata (Hedw.) Web. et Mohr. (from Moscow Province, Zvenigorod biological station Ignatov 1998). 1 - 13600x; 2 - 10400x.

The fact of the rapid distribution of Schistostega in last decade(s) is contrasted with the rather sheltered habitats of the species and with the inability of fresh spores to be dispersed by wind.

\section{MORPHOLOGICAL ADAPTATIONS TO ZOOCHORY}

The first observation on the low ability of spores to be dispersed by wind was published by Gaisberg \& Finckh (1925), but their interesting paper remains not widely known. These authors found spores glued together in clusters, which are partly exposed from the capsule mouth, and concluded that "Die Verbreitung erfolgt wahrscheinlich durch Tiere" (cf. Fig. 15).

Our observations confirm these data. In the course of the study of different species for spore release by wetting and drying of capsules, we tried also Schistostega and found that spores of this species are very sticky in fresh material, impossible to be blown out from capsule even after drying (few days stay in laboratory). At the same time, foreceps became covered by many spores after each touch of a specimen. Also, numerous small spiders, mites and beetles walking through "Schistostega-forest", sometimes climbing upon plants, were more or less dirty of spores, apparently of Schistostega. After wetting spores floated in the water layer along outer capsule wall and seta, but after drying they remained attached to these parts of plant.

The similarly sticky spores are known only in species of Tetraplodon, Splachnum and Aplodon (Koponen \& Koponen, 1977; Koponen, 1990; Demidova \& Filin, 1994), i. e. those which are well-known for the entomochorous mode of the spore disperse. Our study of spores of Schistostega reveal that their ovoid shape and pitted-reticulate ornamentation (Figs. 1,6) are very similar to those of the above mentioned 3 genera of Splachnaceae. Note that spores of all other genera of mosses studied by SEM are variously papillose to verrucose (Boros \& al., 1993). The latter pattern was observed by us in Mittenia.

The possible zoochory lead us to compare some morphological characters of Schistostega and Splachnaceae, especially those considered as adaptations to entomochory by Aune Koponen (1990) and Demidiva \& Filin (1994). They are as follow:

1. The seta which continues growth after capsule opening was noted by Koponen (1990) as a character known only in Splachnaceae. But this is true also in Schistostega. Moreover, in this species capsule is developed very fastly without any seta formation and often operculum is falling off in still sessilous capsule (Figs. 3I, 16-17), and only then seta starts to grow. We have observed very few operculate capsules a little emergent from perichaetia in some, not many of our collections; note, however, that illustrations of Noguchi (1974) and Crum \& Anderson (1981) show operculate capsules on rather developed setae. At early stages of capsule formation its basal part is surrounded by very lax spongy tissue with paraphyses reaching " $1 / 3$ of capsule length", and small perichaetial leaves at the level of capsule base (Figs. 3I, $16,17)$. After seta elongation, vaginula of quite common appearance is developed.

2. The pellucid seta in Schistostega is composed of long-rectangular thin-walled cells with scattered round chloroplasts. In the shade it looks more light than all other parts of plants, having an aspect of fluorescence by glaucousgreen, "phosphorous" color (Fig. 11, 15).

3. Elliptic thin-walled spores. The regularly elliptic spores (Fig.6) are known only in Schis- 


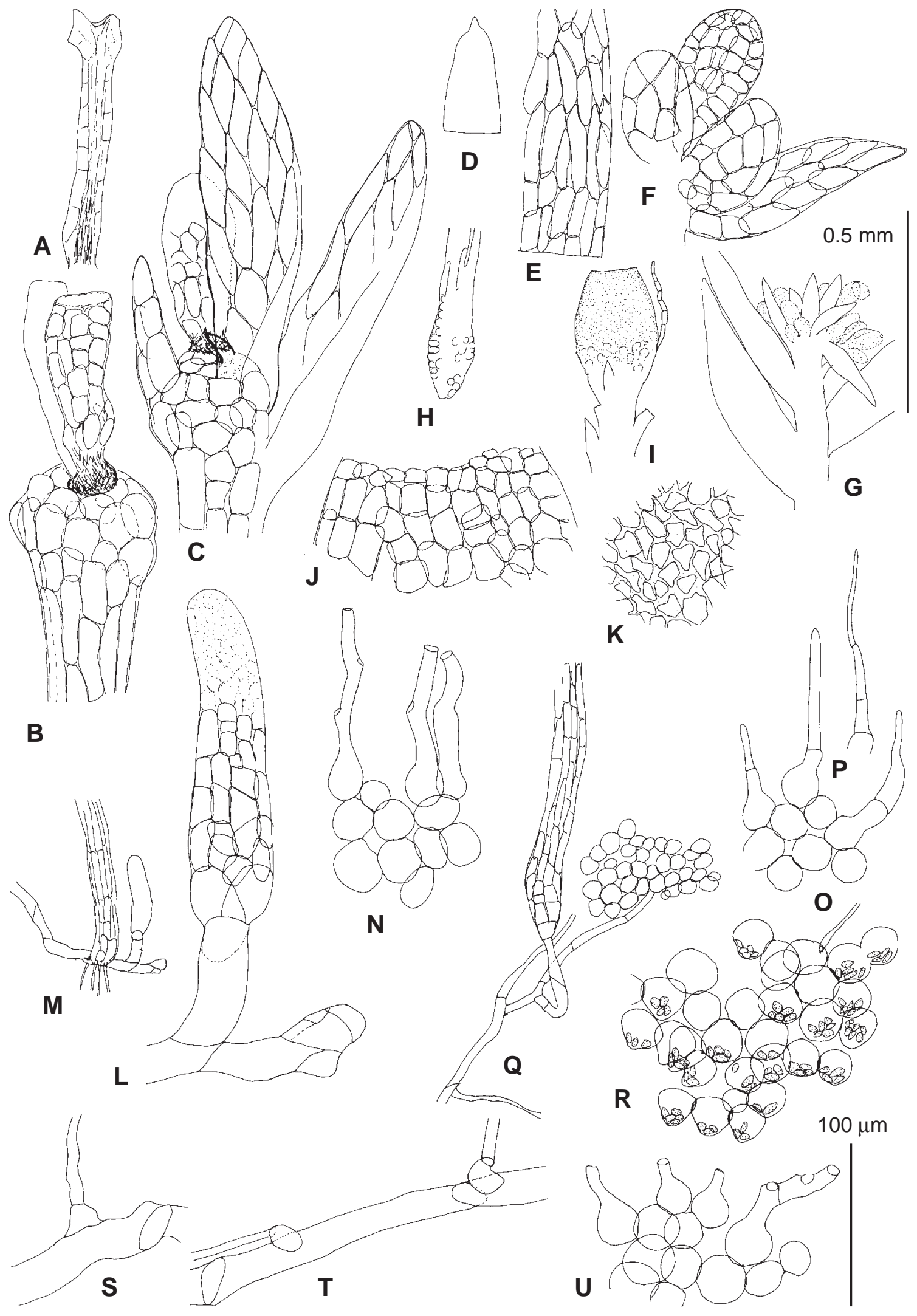


tostega and some entomochorous Splachnaceae (cf. Boros, 1993). The adaptive sense of this is obvious, since the deviation from the sphaeric shape leads to increasing of ratio surface to volume, which increases the attach possibilities. Spore walls are thin, judging from the clearly visible chloroplasts.

4. The colored and thick-walled cells in upper part of capsule of Schistostega are deep brownish to purplish, well contrasting with the bright-green mass of spores. The latter are bright and somewhat shiny (similar to those of Splachnum and Tetraplodon), apparently due to thin walls of spores. Contrasting green spores / deeply colored urn (and also peristome teeth in entomochorous Splachnaceae) were suggested as one of adaptiations for insect attraction in Splachnaceae (cf. Demidiva \& Filin, 1994). The thickenings of exothecial cell walls are developed during the period of seta elongation: young sessilous capsules have thin-walled exothecium cells, while on deep-colored capsules they have almost stellate luminae (cf. Figs. 3J-K)

5. Invariably intermixed occurrence of male and female plants, and frequent sporophyte production. This is a case of autoicous sexual condition, which adaptive sense is obvious - one spore can potentially start a new bisexual population. This ability seems to be very important for species adapted to very specific type of habitats.

However many species of Splachnum and Schistostega are sometimes considered as dioicous. The distribution of gametangia in these species needs certain comments.

According to desriptions (Crum \& Anderson, 1981; Abramova \& al., 1954, etc.) Schistostega is dioicous, but with male and female plants originating from the same protonema. According to our observations, shoots of Schistostega are more or less clustered in growth, usually by (5-)1020(-50) shoots, and in some clusters both male and female shoots are present. Careful diggings in these clusters show caulonemata connection between shoots (thus clusters can be assumed as monophyletic), and sometimes (at least two clear observations) between male and female plants.

Young shoots are never appearing from the older shoot itself, but from caulonemata arising from the most basal part of developed shoot. Caulonemata is branching and its main axis gets orthotropic growth and starts new gametophore, while sympodial axis continues the population expansion (Fig. 3, L-M). First, an ovate, cucumber-like body is developed on the top of orthotropic caulonemata, then it elongates, along with the cell differentiation. Since gametophore reaches ca. $1 \mathrm{~mm}$ long, 1-4 linear leaves becoming apparent on its top, and later this almost leafless "sticklet" differentiates toward fertile or sterile adult shoot.

This case is different from the average dioicous one, since plants seems to be able constantly produce opposite sex, and thus represent a special variant of autoicous condition.

There are different opinions on sexual condition of some species of Splachnum, but some of them, like $S$. rubrum and S. luteum are always mentioned as dioicous (Crum \& Anderson, 1981; Savicz-Ljubitskaya \& Smirnova, 1970). However, the mutual occurrence of both sexes on the same piece of excrement in most of collections let us to investigate these species thoroughly. Since plants are fragile and stems in herbarium specimens are coming from quite solid dry excrement, we treated them first by hot water. After the substrate became soft enough, we were able to trace the connections of shoots and found that both these species are in fact autoicous (two cases for each species). The connection between male and female shoots occurs very close to the level of substrate, so the differentiation into male and female shoots must be at very early stage of developement. Later both male and female shoots are branching strongly, forming unisexual groups of ultimate shoots.

So, the mechanisms of keeping together both sexes in Schistostega and entomophilous Splachnaceae are different, but the result is the same - one spore can potentially start a new bisexual population.

Fig. 3. Schistostega pennata (Hedw.) Web. et Mohr (from Moscow Prov., Ignatov 10.VII.2000, MHA): A - neck of archaegonium fallen from its lower part shown in B (after fertilization?); B-C - upper part of female stem with lower parts of archaegonia; D - calyptra; E - cells of calyptra; F-G - upper part of male stem with antheridia; H - foot of seta; I capsule at early stage of developement; $\mathrm{J}$ - exothecial cells from sessilous capsule; $\mathrm{K}$ - exothecial cells from highly exserted capsule; L-M - young shoot; N-P, U - parts of vesiculate protonemata with gemmae or places of their breakage; Q filamentose protonema with base of shoot and "umbrella" of vesiculate protonema; R - vesiculate part of protonema; S-T caulonema, with its thin branches. Scale bars: $0.5 \mathrm{~mm}$ for D, G-I, M, Q; $100 \mu \mathrm{m}$ for A-C, E-F, J-L, N-P, R-U. 


\section{OTHER INTERESTING AND POSSIBLY ADAPTATIVE CHARACTERS IN SCHISTOSTEGA}

1. Not only spores of Schistostega are sticky. Edwards (1978) nicely described protonematal gemmae in Schistostega and found them also very sticky and attched to bodies of small insects and mites. We observed similar cases for small mites and Collembolae. This is certainly an important factor of disperse of Schistostega within one upturning, though long-distance dispersal by these animals is unlikely due to their limited migration ability.

2. The rare phenomenon of luminous protonema is explained by the specific aggregation of chloroplasts near lower cell wall (Fig. 5). This character is rare, but not unique in mosses: it occur also in Mittenia, which also grows in shady places, but hardly can be considered as obliged zoochoric species - it has double peristome and verrucose, probably not sticky spores (fresh spores not studied). The similar distribution of chloroplasts in cells occurs in fern gametophytes (probably, Athyrium filix-femina), which grow on wet upturnings too. Therefore, the chloroplast aggregation at lower cell wall can be considered as an adaptation to shady environments. Since the luminous effect depends probably on this chloroplast position, one can conclude that this effect was not a subject of natural selection and not necessarily is an adaptation. However, speculations on the adaptive sense of luminous effect are possible in two directions: (1) luminous effect can attract some animals, which increase dispersal ability of the species; or, contrary, (2) luminous effect might work as a repellent signal, indicating soil wall, which is not always clearly visible in shady caves and holes; in this case, the favor of Schistostega is in protection of its own micro-habitats, which can be very easily destroyed even by a slight touch. Both hypotheses however can be tested only by a rather elaborated experiments involving animals.

The structure of the aggregations of vesiculate cells is very peculiar. At lower magnifica- tion they look like plates or umbrellas (Fig. 3Q, 9-10, 12). However, under compound microscope, one can find, that sphaeric vesiculate cells are arranged in filaments, at places branching, and anastomozing (due to very sticky surface?) by very small areas of cell walls (Figs. 3R, 3U, 4). It is amazing, how these aggregates can select the optimal position perpendicular to the source of light - we can judge about this by the oneside directed protonemal "umbrellas" (Figs. 910, 12). According to our observations in cultivation, once collapsed by drought and fallen on soil surface, vesiculate protonema can not stand again after moisture increasing, and only after certain time of living in sufficient moisture can develope new "umbrellas" of vesicules.

3. Very thin branches of caulonemata can also be considered as an adaptation to fast colonization of open substrates. Usually, branch is sitting not on thicker caulonemata itself, but on short conic cell. This organization allows the branch of rhizoids keep direction not necessarily \pm perpendicular to the main axis, but sometimes nearly parallel to the latter (Fig. 3J, 3R). This ability seems important for growth along much eroded surface, spreading upon and between sand grains, etc.

4. One more adaptation is connected with the reduction of archaegonium number to just 1-2. This means that Schistostega must have rather perfect ability for spermatozoid delivery to every archaegonium. This is not obviously easy, because in Schistostega fertilization takes place in "canopy", like in Polytrichum, because of the absence of continuous liquid water medium between shoot tops. This can be concluded from the fact, that tufts of Schistostega are never "continuously watering”, like in many other mosses. According to our observation, soil in populations of Schistostega remains dry after rain (cf. chapter on ecology below), and after strong rain drops of water are confined just to shoot ends. The surface of fresh leaves of Schistostega is rather hygrophobous, judging from how difficult is

Figs. 4-17. Schistostega pennata (Hedw.) Web. et Mohr (photographs were made through compound and dissecting microscopes in laboratory, using fresh material from nature): 4-5 - cells of vesiculate protonema, 500x and 1400x; 6 spores, 1000x; 7-8 - gemmiferous cells with broken (7) and still present (8) gemmae, 450x and 220x; 9-10, 12 protonema "umbrellas", showing parallel arrangemt of "umbrellas" (and perpendicular to source of light), 50x; 11 plants with sporophytes; 13-15 - capsules, 80x; 16-17 - open sessilious capsule, immersed by its base to spongy tissie of upper stem, $80 \mathrm{x}$ and $200 \mathrm{x}$. 

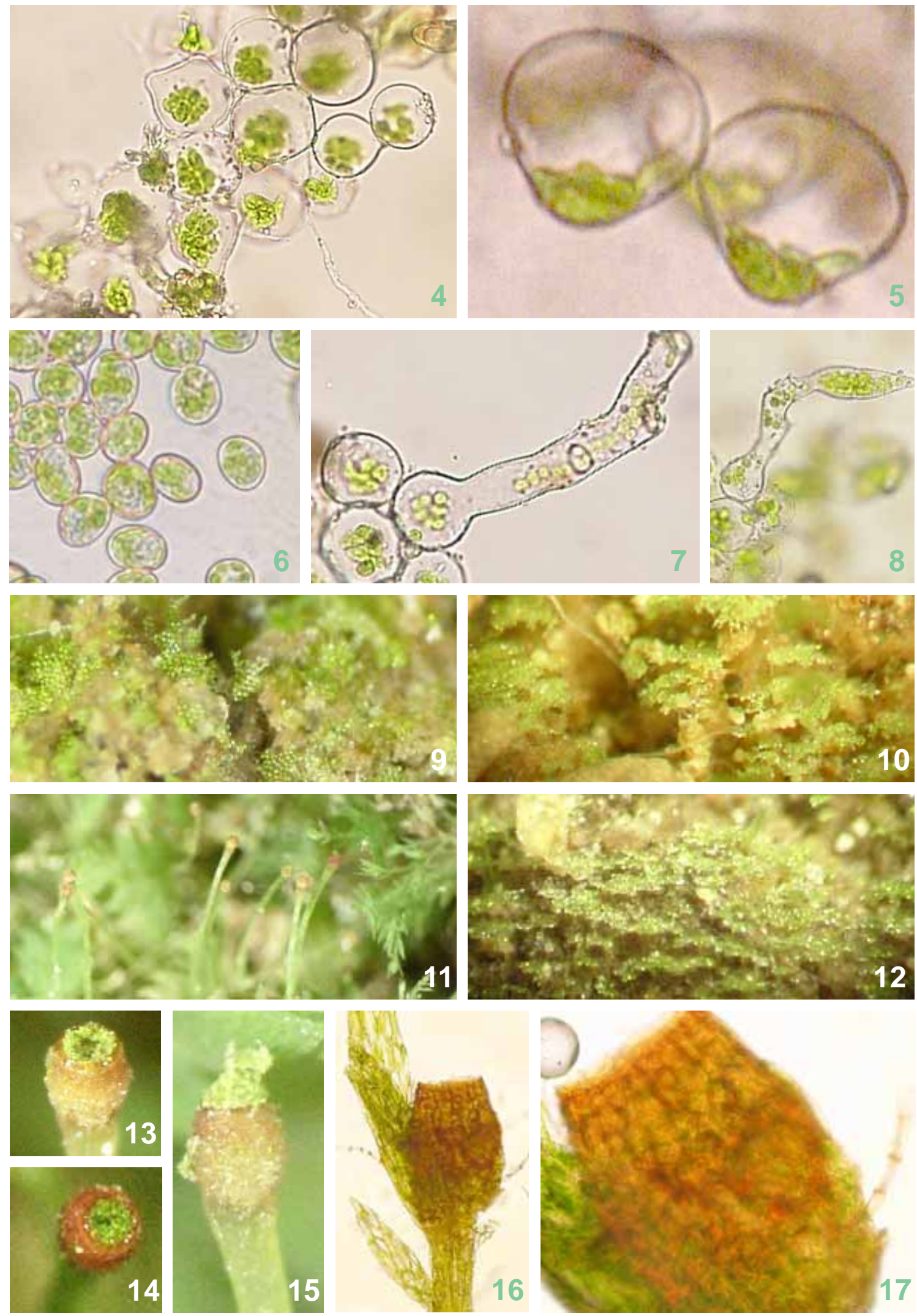

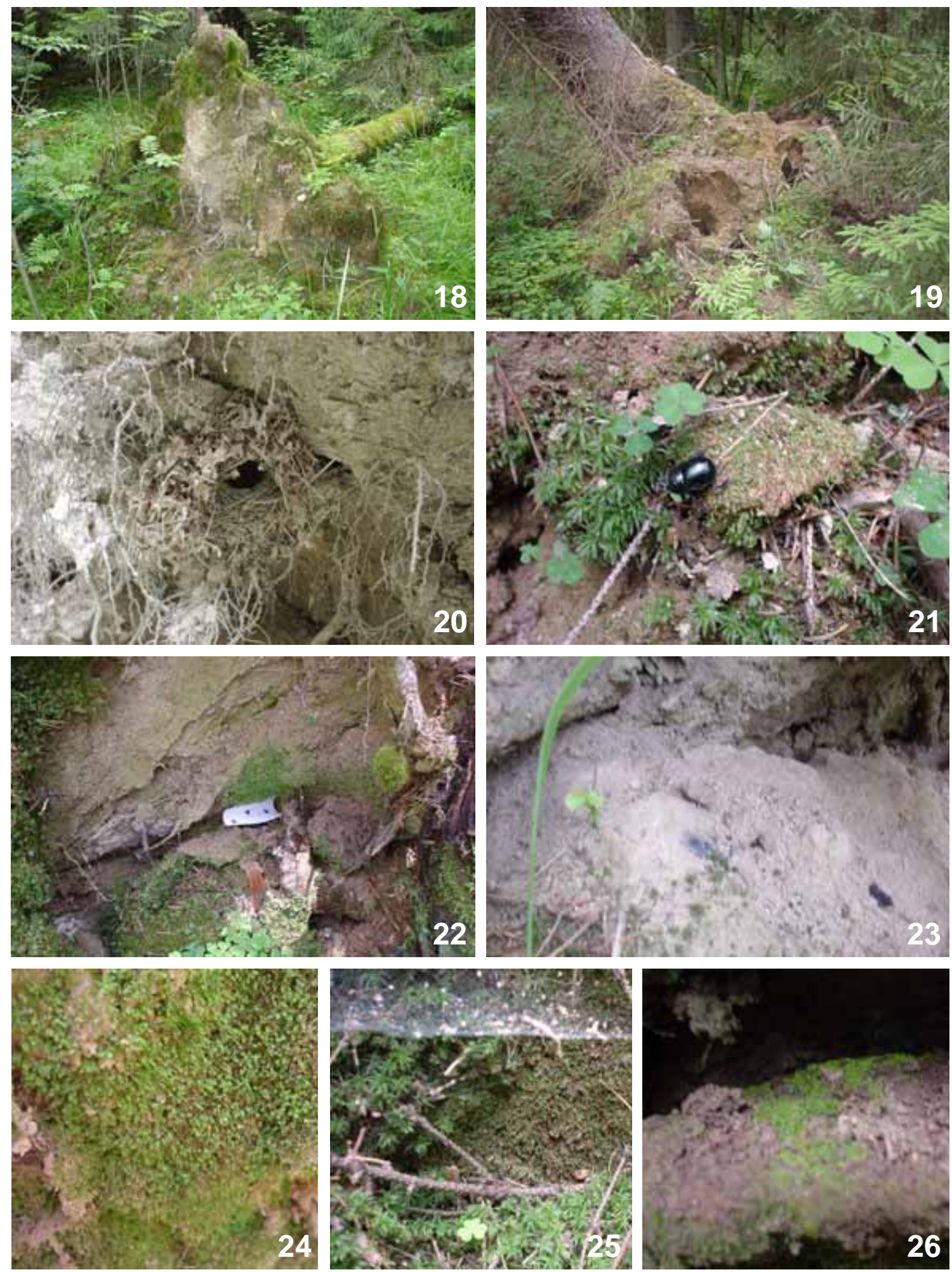

Figs.18-27.Habitats of Schistostega pennata (Hedw.) Web.et Mohr.18 - averageappearance of upturning with Schistostega; 19 - inclined and later sawed spruce,formed narrow nishes under roots; 20 - nest of Trogloditus on upturning; 21 - Geotrupes stercorarius (beetle) among Schistostega; 22 - upturning with piece of sticky paper; 23- "bird swimming pool" with remains of beetle Geotrupes (blue spot); 24 - Schistostega cover; 25 - spider web above Schistostega population; 26 - path to hole under upturning, marked by protonema of Schistostega. 

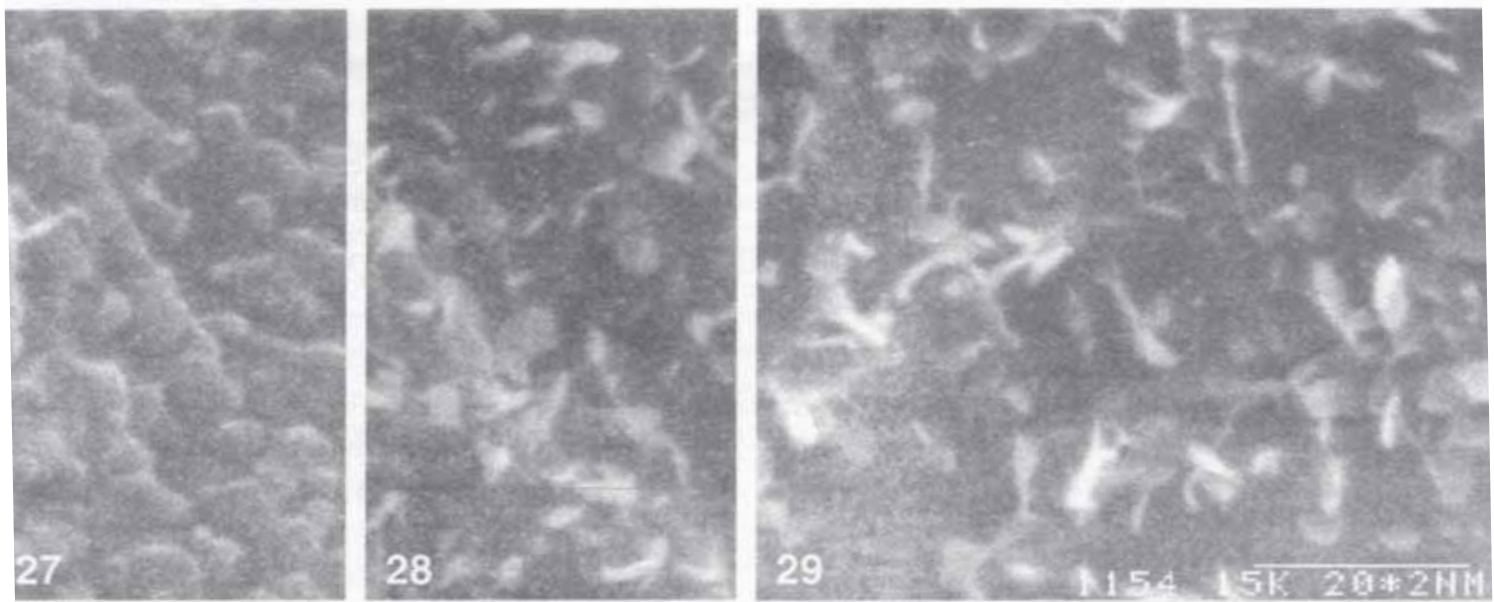

Fig.27-29.Surface of leaves of Schistostega pennata (Hedw.) Web.et Mohr.(from Moscow Province,Zvenigorod biological station Ignatov 1998). - 10400x.

to wet them when preparing water-slide. Also, the leaf surface is covered by granulae and spiculae, probably of wax compounds (Figs. 27-29). So, spermatozoids must reach female plants from top to top (directly or indirectly). And this appears to be possible due to: 1) growth on vertical walls; 2) male shoots have a spirally twisted surface cells and twist counterclockwise after wetting. Then growing in caves and deep overgangs, Schistostega seems can be wetted by the water vapour condensation in drops at shoot ends.

\section{OBSERVATIONS ON HABITATS OF SCHISTOSTEGA}

In many parts of the world Schistostega is usually assocoated with rocky places, for example in Norway (Lye, 1972) and Japan (Kanda, 1971). In Poland, Ochyra \& al. (1988) described Schistostega habitats as follow: "deep fissures and cracks in siliceous or other noncalcareous rocks, overhangs, walls of excavations and deep holes as well as hollows made by uprooted by wind trees". This set of habitats is also mentioned by Crum \& Anderson (1981) for Eastern North America, and it is amost the same in mountain areas of Russia which we studied, i. e. Urals, Altai, Bureya Range in Khabarovsk Territory. Note, that Schistostega was not found in calcareous areas of Yakutia and Western Caucasus. Since the most part of Central Russia has no rocks, the only habitat of Schistostega here is soil walls at upturned roots of fallen trees (especially those of coniferous trees).
Our observations on Schistostega in the Zvenigorod Biological Station of Moscow University have been done in 1998-2000.

The Biological station is situated ca. $50 \mathrm{~km}$ West of Moscow, at watershed and terraces of Moscow River in its upper course. The watershed has sandy to loamy soils, and old Pinus sylvestris ${ }^{1}$ forest, which is fastly replacing now by Picea abies. There are also scattered secondary Betula pendula and B. pubescens stands, and old spruce forest without pine; scattered are also broad-leaved trees. Slopes to Moscow River have more broad leaved trees (Tilia cordata, Acer platanoides, Quercus robur), but spruce remains a dominant here too. Both spruce and broad-leaved stands on slope to Moscow River often have rather dense Corylus avellana shrubs. The herbaceous layer is dominated in watershed area by Oxalis acetosella; Calamagrostis arundinacea; Carex pilosa, Vaccinium myrtillus, rarer Vaccinium vitis-idea, sometimes it is multi-herbacous, meadow-like; among mosses at places are common Pleurozium schreberi, Brachythecium oedipodium, Ptilium crista-castrensis. On slope to Moscow River more common are nemoral herbs, like Carex pilosa, Aegopdium podagraria, Mercurialis perennis, Galeobdolon luteum, etc.

Forest in the station has been cut only in few plots, and in most of its parts trees are of 60-80(-100) years old.

\footnotetext{
1 - Nomenclature of vascular plants is according to Cherepanov (1995); of mosses - accorfing to Ignatov \& Afonina (1992).
} 
Table 1. Characteristics of habitats Schistostega on upturnings in Zvenigorod biological station. Age was estimated by moss cover on fallen log; light was visually estimated from 1 to 5 ; soil moisture is percent of loss of water : dry weight of specimen (Baskina \& al., 2000).

\begin{tabular}{|c|c|c|c|c|c|c|c|c|}
\hline $\mathrm{N}$ & tree & age & $\begin{array}{l}\text { azimut of } \\
\text { log top, }\end{array}$ & $\begin{array}{l}\mathrm{h} \text { above } \\
\text { ground, } \mathrm{cm}\end{array}$ & light & $\begin{array}{l}\text { frequency and capsules } \\
\text { and protonema presence }\end{array}$ & $\begin{array}{r}\mathrm{pH}, \\
\text { water }\end{array}$ & $\begin{array}{r}\text { soil } \\
\text { moisture }\end{array}$ \\
\hline 1 & Picea & old & 340 & 45 & 3 & common, with capsules (caps) & 4.91 & 20.4 \\
\hline 2 & Picea & old & 340 & 10 & 3 & common, caps & 4.97 & 19.0 \\
\hline 3 & Picea & old & 340 & 40 & 3 & common, caps & 5.25 & 20.1 \\
\hline 4 & Picea & old & 320 & 30 & 5 & common, partly dry & 5.68 & 20.4 \\
\hline 5 & Picea & young & 20 & 45 & 3 & sparse, caps & 4.81 & 18.9 \\
\hline 6 & Picea & young & 300 & 35 & 3 & rare, with protonema (prot) & 4.50 & 22.6 \\
\hline 7 & Pinus & old & 40 & 30 & 4 & sparse, caps+prot & 5.38 & 22.0 \\
\hline 8 & $?$ & old & 225 & 15 & 4 & common, caps + prot & 5.39 & 17.4 \\
\hline 9 & Picea & old & 320 & 25 & 5 & rare, caps & 4.77 & 18.5 \\
\hline 10 & Betula & old & 120 & 15 & 4 & sparse, partly dry & 4.91 & 17.1 \\
\hline 11 & Betula & medium & 150 & 20 & 2 & sparse, caps & 4.64 & 17.7 \\
\hline 12 & Betula & medium & 280 & 5 & 1 & sparse, caps & 4.90 & 17.2 \\
\hline 13 & Betula & old & 30 & 30 & 3 & common, caps & 4.62 & - \\
\hline
\end{tabular}

The results of observations are as follow:

1. Within the station, ca. $5 \times 5 \mathrm{~km}$, Schistostega was found on most of upturnings in the watershed area, without clear preferences to forest type. Forests on slope to Moscow River have Schistostega in very few places. Two forests outside biological station, 7 and $3 \mathrm{~km}$ apart (4-5 km of the Hwy, and $0.5 \mathrm{~km}$ North of Shikhovo village), were studied for Schistoste$g a$. Though the forest composition is almost similar to that in watershed within the Biological Station, it is used for silviculture, and have rather few fallen trees. Only few upturnings suitable for Schistostega were found in these two places, but neighter of them had $\cdot$ Schistostega.

2. One area, ca. 100 hectars, was studied more detaily. Among 39 upturnings in this area, Schistostega was found on 32. Most of these upturnings are faced to the South, which probably depends on the direction of strong wind, an immediate reason of tree fall. However there are also differently orientated upturnings. The presence/absence of Schistostega does not correlate with direction of fallen tree.

3. The absence of Schistostega in some upturnings is not correlated with their more remote position from others, and probably has an occasional pattern. The isolation by several hundred meter do not prevent the ready distribution of Schistostega.

4. Schistostega is usually absent on the upturnings of less than one year old, and often already present of upturnings of ca. 1.5 year old. In the latter it is present usually only at the lowermost part of upturning.

5 . The moisture of soil and $\mathrm{pH}$ were studied for 10 upturnings (Baskina \& al., 2000). They were selected to cover maximal diversity in moisture and $\mathrm{pH}$. However results show rather low diversity of these parameters (Tabl. 1). $\mathrm{pH}$ varies within 4.50-5.68, which falls within the range found in Latvia - 4.32-6.23 (Apinis, Lacis, 1936), and in Japan - 4.2-6.8 (Kanda, 1971). Soil moisture was found rather constant and dry (Tabl. 1).

6. Schistostega is usually considered as a moss of shady habitats. However in the Zvenigorod biological station we found it in habitats of quite different light condition, sometimes on very sunny places. The light condition was evalutated by a canopy density from 1 (very shady) to 5 (almost open). Most upturnings with Schistostega have medium light condition. Upturnings with the abundant Schistostega also are mostly moderately lightened. This can be illustrated by data from 80 upturnings with Schistostega, in 28 of which the moss was in abundance:

$\begin{array}{llllll}\begin{array}{l}\text { Light } \\ \text { Upturnings with }\end{array} & 1 & 2 & 3 & 4 & 5 \\ \begin{array}{l}\text { Schistostega, \% } \\ \text { स. with abundant }\end{array} & 12 & 33 & 31 & 16 \\ \begin{array}{l}\text { Schistostega, \% } \\ \text { P }\end{array} & 20 & 50 & 15 & 10 \\ \quad \text { Probably, more shady condition (mostly due } \\ \text { to abundant Corylus) in broad-leaved forests } \\ \text { on slope to Moscow River is a reason of its } \\ \text { rarity in this place. }\end{array}$


7. Schistostega grows in upturnings for several years, and then is substituting by Dicranella heteromalla and Atrichum undulatum, species common for this type of habitats in Moscow Province. These mosses replace Schistoste$g a$ on upper and inclined surfaces, but can not easily grow on vertical, overhanging and roofed inclined surfaces, where Schistostega remains probably for many years: it was found on some upturnings with very strongly decomposed logs, no less than 10 years old.

\section{POSSIBLE DISPERSAL AGENTS OF SCHISTOSTEGA}

As it was mentioned before, Sluka (1986) published a list of bryophytes of the Zvenigorod Biological Station, which does not include Schistostega, so it is obviously either appeared or increased greatly in the last decade. At the same time, the inability of spores to be dispersed by wind, put the question about a transmitter of diaspores from one upturning to another.

There are several animals which could distribute spores and sticky protonemal gemmae of Schistostega from one upturning to another one in this forest: 1) Arthropoda: insects, spiders and mites; 2) birds; 3) mice; 4) frogs. Bats, which can be considered as a possible transmitter of Schistostega in mountain areas, are never visiting upturnings in forests of Moscow Province (K. Panyutin, pers. com.).

\section{ARTHROPODA}

Spiders, mites and insects were studied by visual observations, and also were caught by pieces of sticky paper, positioned in upturning with Schistostega for 1-2 days (Fig. 22)

The most numerous insects (excluding Collembolae) near upturnings are mosquitous. In hot day time they are often concentrated in milder microclimate of upturnings. However they were never observed sitting on Schistoste$g a$ itself: for rest they select usually small hanging roots. When a mosquito touches Schistoste$g a$, it probably does not press it strongly enough to be sticked by Schistostega spores. At least 4 specimens of mosquitous caught by sticky paper have no one spore on their legs.

The similar observation has been made for a diptera (all identifyed by A.Shatalkin) of family Empididae, genus Hybos.

Flies are also common, the species of families Phoridae, Muscidae and Dolichopodidae were cought by sticky paper. The specimens of Dolichopodidae were observed in only one place, in rather swampy forest, but bodies of 2 specimens cought by sticky paper were covered at places by spores, probably belonging to Schistostega.

In two upturnings with Schistostega nests of vesps (Vespula sp.) were seen. Few these insects were caught by sticky paper, but then escaped.

Some ants (Formica rufa L.) and beetles (Geotrupes stercorarius L.) were seen climbing upturnings among Schistostega, and on the body of beetle some spores were attached.

However, in general rather naked bodies of insects have few spores, comparatively with more hispid legs of spiders. Attached to sticky paper were species of the genus Trochosa, and of the order Opiliones (det. K. Mikhailov).

Several insects and spiders with putatively Schistostega spores were studied under SEM. However, only papillose spores and pollen grains were observed attached to insects. Probably (if our interpretation of Schistostega spores under light microscope was correct), they fall off the insect blown in vacuum in SEM body.

\section{BIRDS}

(a) Troglodytes troglodytes (L.), one of the smallest birds of Central Russia, lives typically in spruce forests with tree falls. It often looks for insects at upturned roots, and sometimes also is nesting in this type of habitats. One nest was found in the Biological Station, attached to roots in central part of the upturning of ca. 1.5 years old, with few mosses (Fig. 20). Protonema of Schistostega occurs in this upturning along the base of soil wall (as usual in recent upturning). But one more patch of Schistostega was also found in flat upper part of upturning, the best place for bird to sit outside the nest, before getting in the nest. Troglodytes was seen many times flying off the upturning after our coming.

(b) Tetrastes bonasia (L.), rather big bird of cock family, also quite common in old spruce forests. Since the soil in many upturnings is rather dry, birds use horizontal spots of them as "bird swimming pools" ["swimming" in dry dust]. Probably many birds use upturnings for this purpose, but all feathers found in 3 such places belong to Tetrastes. "Bird swimming pools" often have walls with Schistostega. Feathers from some of them have attached spores 
of Schistostega - they were attached to pinnae and recognized by elliptic shape and size of ca. $10 \mu \mathrm{m}$. Since feathers were rather old, no chloroplasts were observed in these spores. Attempts to confirm the identity of spores by SEM was not successful.

(c) Some birds before eating of a relatively large beetles, like Geotrupes (Fig. 21), need to find first a flat place to divide it into smaller parts. Blue spots from Geotrupes were found on soil of trails, and sometimes also on flat places in upturnings (Fig. 23). This is one more possibility for spore disperse on body of this beetle, which is rarely flying and therefore can not be an active disperser of Schistosega spores itself.

\section{MICE.}

The mouse holes were seen under many uprurnings. The probable disperse of spores by mice have two evidences: (1) in some very recent upturnings protonema of Schistostega was found only along the base of soil wall; (2) in the hole under little upturned roots ca. 1.5 years ago (Fig. 19) we found some patches of protonema in deep shade, ca. $40 \mathrm{~cm}$ from the entrance; no insects and arthropodes were caugth by sticky paper in this place, but few hairs of an animal, apparently one of mice species, were found on sticky paper in this place.

\section{FROGS.}

No clear evidences on this group were found, though some Rana species were seen in the habitats with Schistostega. The evidence 1 of mice is valid also for frogs. The permanently wet skin of frogs can also be a good conservant to thin-walled, and therefore drought-sensitive Schistostega diaspores.

\section{CONCLUDING REMARK}

Zoochory usually means that the diaspores are distributed by animals. In fact, many mosses have some structures adapted to animal dispersal.Say,fragile leaf tips,or axillary brood branches and brood filaments can be dispersed mostly by animals, because without mechanical affect they would remain on the plant and fall right within its tuft. In this sense, zoochory is a very common mode of disperse in mosses. However, most of moss species are able also to produce spores, which can be dispersed by wind. Sticky spores which can not be transported by wind are rare in mosses and this is the more obliged case of zoochory. At moment only three genera of Splachnaceae are know strictly adapted to the distribution of spores by insects (Koponen, 1990), and developed special morphologial structures and chemical compounds to attract them. Schistostega has some morphological characters parallel to Splachnaceae, but at moment, adaptations to certain animal can not be demonstrated as clearly as for Splachnaceae.

Schistostega is certainly more flexible to disperse agents depending of the area. For example, once we found Schistostega in Altai in cave on steep slope, among dry steppe vegetation. Such caves are very rare in that area, separated one from anoter by kilometers. In such situation, Schistostega seems can be dispersed by bats or big mammals, who are able to cover distance to the next suitable place in reasonable time.

The situation in virgin forests with numerous tree-falls is different, and here Schistostega can probably be dispersed by many groups of animals. However further observations are necessary to understand the most effective distributor among insects, spiders, mice, birds and frogs.

\section{ACKNOWLEDGMENTS}

Authors are grateful for numerous consultation on various groups of animals to A. I. Shatalkin, A. V. Sviridov (insects), K. G. Mikhailov (spiders), I. Pokrovskaya, I. Taldenkov (birds), K. Panyutin (mammals). Various comments on manuscript has been done by $\mathrm{V}$. R. Filin, T. Koponen, and especially A. Koponen. Data on ecology of Schistostega in Zvenigorod Biological Station were collected by S. L. Baskina, N. V. Grechanaya, N. V. Rogova, T. A. Khudyakova, E. A. Chikurova, during their student work in 2000. The study of the authors were partly supported by the Russian Foundation for Basic Researches, grant 99-04-48194.

\section{LITERATURE CITED}

[ABRAMOVA, A. L., K. I. LADYZHENSKAYA \& L. I SAVICZ-LJUBITSKAYA] АБРАМОВА, А. Л., К. И. ЛАДЫЖЕНСКАЯ, Л. И. САВИЧ-ЛЮБИЦКАЯ 1954. Андрэевые и бриевые (тетрафисовые, политриховые, буксбаумиевые, шистостеговые) мхи. - [Andraeales, Tetraphidaceae, Polytrichaceae, Buxbaumiaceae and Schistostegaceae] Флора споровых растений СССР [Flora sporovykh rastenij SSSR] 3, 331. 
APINIS, A. \& L. LACIS 1936. Data on the ecology of bryophytes. II. Acidity of the substrata of musci. - Acta Horti Bot. Univ. Latviensis (Riga) 9/10:1-100.

[BASKINA, S. L., N. V. GRECHANAYA, N. V. ROGOVA, T. A. KHUDYAKOVA \& E. A. CHIKUROVA] БACКИНА, С. Л., Н. В. ГРЕЧАНАЯ, Н. В. РОГОВА, Т. А. ХУДЯКОВА, Е. А. ЧИКУРОВА 2000. Биология и распространение Schistostega pennata (Hedw.) Web. et Mohr. - [Biology and distribution of Schistostega pennata (Hedw.) Web. et Mohr] Pукопись, каф. геоботаники Биол. ф-та МГУ [Msc. in Dept. of Geobotany, Biol. Faculty, Moscow State Univ. ], 22 pp.

BECKERT, S., S. STEINHAUSER, H. MUHLE \& V. KNOOP 1999. A molecular phylogeny of bryophytes based on nucleotide sequences of the mitochondrial nad5 gene. - Plant Syst. Evol. 218: 179-192.

BECKERT, S., H. MUHLE, D. PRUCHNER \& V. KNOOP 2001. The mitochondrial nad2 gene as a novel marker locus for phylogenetic analysis of early land plants: a comparative analysis in mosses. - Molecular Phylogenetic and Evolution 18(1): 117-126.

BOROS, A., M. JARAI-KOMLODI, Z. TOTH \& S. NILSSON 1993. An atlas of recent European bryophyte spores. - Budapest, Academic Press, 319 pp.

BUCK, W. R. \& B. GOFFINET 2000. Morphology and classification of mosses. - In: Shaw, A. J. E. \& B. Goffinet (eds.) Bryophyte biology, Cambridge, Cambridge Univ. Press.: 70-123.

[CHEREPANOV, S.K.] ЧЕРЕПАНОВ, С. К. 1995. Сосудистые растения России и сопредельных государств. [Vascular plants of Russia and adjacent states] СПб, Мup и семья-95 [Sankt-Petersburg, Mir I sem'ya-95]: 990 pp.

CRUM, H. A. \& L. E. ANDERSON 1981. Mosses of the Eastern North America. N-Y, Columbia Univ. Press. $1328 \mathrm{pp}$.

FISCHER-WALDHEIM, A. 1864. Florula bryologica Mosquensis. - Moscow, 160.

DEMIDOVA, E. E. \& V. R. FILIN 1994. False columella and spore release in Tetraplodon angustatus (Hedw.) Bruch et Schimp. in B. S. G. and T. mnioides (Hedw.) Bruch et Schimp. in B. S. G. (Musci: Splachnaceae). Arctoa 3: 1-6.

EDWARDS, S. R. 1978. Protonemal gemmae in Schitostega pennata (Hedw.) Web. et Mohr. - J. Bryol. 10: 69-72.

GAISBERG, E. V. \& E. FINCKH 1925. Zur Biologie von Schistostega osmundacea. - Flora 20: 143-175.

IGNATOV, M.S. \& O.M. AFONINA (eds.). 1992. Checklist of mosses of the former URRS. - Arctoa 1: 1-85.

[IGNATOV, M. S. \& E. A. IGNATOVA] ИГНАТОВ, М. C., Е. А. ИГНАТОВА 1990. Материалы к познанию бриофлоры Московской области. - [Contribution to the bryoflora of Moscow Province] В кн: Флористи ческие исследования в Московской области (ред. Сквориов, А. К.), М., Наука [In: Skvotsov, A. K. (ed.), Floristicheskie issledovaniya v Moskovskoi oblasti]: 121-179.

[IGNATOV, M. S. \& E. A. IGNATOVA] ИГНАTOB, М. C., Е. А. ИГНАТОВА 1991. Бриофлора Приокско-Террасного государственного биосферного заповедника. -
[Bryoflora of Prioksko-Terrasnyj Biosphere Reserve] $B$ кн: Изучение экосистем Приокско-Террасного государственного биосферного заповедника (Керженцев, А. С. (ред.), Пущино-на-Оке, АН СССР, Пущинский Научн. Центр [In: Kerzhenzev, A. S. (ed.) Izucheniye ekosistem Prioksko-Terrasnogo Gosudarstvennogo biosphernogo zapovednika. Pushchino-na-Oke, Akad. Sci. USSR]: 6-20.

[IGNATOV, M. S., E. A. IGNATOVA \& N. P. KHARITONOV] ИГНАТОВ, М. С., Е. А. ИГНАТОВА, Н. П. ХАРИТОНОВ 1988. Заметки о редких и интересных видах мхов Московской области. - [On rare and interesting mosses in Moscow Province] В кн.: Науч ные основы охраны живой природы Подмосковья (ред. B. Н. Тихомиров). М., Наука [In: Tikhomirov, V. N. (ed.) Nauchnye osnovy okhrany zhivoi prirody Podmoskov'ya. Moscow, Nauka]: 21-28.

IGNATOV, M. S., E. A. IGNATOVA, E. N. KURAYEVA, T. YU. MINAYEVA \& A. D. POTEMKIN 1998. Bryophyte flora of Zentralno-Lesnoj Biosphere Natural Reserve (European Russia, Tver Province). - Arctoa 7: 153-188.

KANDA, H. 1971. Schistostega pennata Hedw. in Hokkaido: its ecology and germination. - Hikobia 6(1-2): 60-75.

KOPONEN, A. 1990. Entomophily in the Splachnaceae.Bot. J. Linn. Soc. 104: 115-127.

KOPONEN, A. \& T. KOPONEN 1977. Evidence of entomophily in Splachnaceae (Bryophyta). - Bryoph. Bibl. 13: 569-577.

LYE, K. A. 1972. Studies in Norwegian bryophytes. 1. The family Schistostegaceae. - Lindbergia 1: 205-213.

[MAJOROV, S. R.] МАЙОРОВ, C. Р. 1999. Данные к бриофлоре Козельского района Калужской области. - [New data on bryoflora of Kozelsk District of Kaluga Province] В кн.: Флористические исследования в Центральной России на рубеже веков: Мат. Научн. Совеш., Рязань, 29-31 января 2001 г. (ред. Новиков, B. C., С. Р. Майоров). М., Ботсад МГУ [In: Novikov, V. S. \& S. R. Majorov (eds.) Floristicheskie issledovaniya $v$ Zentralnoj Rossii na rubezhe vekov. Proc. conf. Ryazan, 29-31 January 2001. Moscow Bot. Sad Mosk. Gos. Univ.]: 85-87.

NOGUCHI, A. 1974. Musci Japonici. XI. The families Disceliaceae, Ephemeraceae, Oedi podiaceae, Splchnaceae, and Schistostegaceae. - J. Hattori Bot. Lab. 38: $387-404$.

OCHYRA, R., P. SZMAJDA, W. BOCHENSKI \& K. KARCZMARZ 1988. Schistostega pannata (Hedw.) Web. \& Mohr. - In: Tobolewski, Z. \& T. Wojterski (eds.) Atlas Rozmieszczenia Roslin Zarodnikowich w Polsce. Ser. 5 Mchy (Musci) 4: 15-17.

[RECZAN, S. P., T. V. MALYSHEVA, A. V. ABATUROV, P. N. MELANKHOLIN] PEЧAH, С. П., Т. В. МАЛЫШЕВА, А. В. АБАТУРОВ, П. Н. МЕЛАНХОЛИН 1993. Леса Северного Подмосковья. - [Forests of Northern Moscow Province] M., РАН, Ин-т Лесоведения [Mоscow, Russ. Acad. Sci., Inst. of Forest Researches], 316 pp.

SAMIGULLIN, T. H., K. M. VALIEJO-ROMAN, A. V. TROITSKY, V. K. BOBROVA, V. F. FILIN, W.MARTIN, A. S. ANTONOV 1998. Sequiences of rDNA internal tanscribed spacers from the chloroplast DNA of 26 
bryophytes: properties and phylogenetic utility. - FEBS letters 422: 47-51.

[SAVICZ-LYUBITSKAYA, L.I. \& Z.N. SNIRNOVA] CAВИЧ-ЛЮБИЦКАЯ, Л.И., З.Н. СМИРНОВА. 1970. Определитель листостебельных мхов СССР. Верхоплодные мхи. - [The Handbook of mosses of the USSR. The acrocarpous mosses] Л., Наука [Leningrad, Nauka], $826 \mathrm{pp}$.

SOEDERSTROEM, L. 1996. Preliminary distribution maps of bryophytes in Northwestern Europae. - Mossornas Vanner, Trondheim. 1-72.

[SLUKA, Z. А.] Слука, 3. А. 1986. Бриофлора. - [Bryoflora] В кн. Растительность и флора Звенигородской биологической станции МГУ. М., Изд-во МГУ [In:
Rastitelnost i flora Zvenigorodskoj biologicheskoi stanzii MGU, Moscow, Izd. Mosk. Gos. Univ.].

STONE, I. G. 1986. The relationship between Mittenia plumula (Mitt.) Lindb. and Schistostega pennata (Hedw.) Web. et Mohr. - J. Bryol. 14: 301-314.

WARNSTORFF, C. 1913-14. Bryo-Geographie des Russischen Reiches. Eine Erinnerung an Dr. E. Zickendrath. - Hedwigia 53: 184-320 \& 54: 22-182.

ZICKENDRATH, E. 1900. Beitraege zur Kenntnis Moosflora Russland. II. - Bull. Soc. Natur. Moscou 14(3): 241-366.

ZHADOVSKY, A. Е. [ЖАДОВСКИЙ, А. Е.] 1928. Реликтовая колония Polypodium vulgare в Калужской области и необходимость ее охраны. - Охрана природы 1(3): 5-13. 